Sains Malaysiana 50(11)(2021): 3303-3311

http://doi.org/10.17576/jsm-2021-5011-14

\title{
Downregulation of WNT8A, LRP5, LRP6 and FGF8 in Malay Non-Syndromic Cleft Lip and/or Palate Patients
}

(Pengawalaturan Rendah WNT8A, LRP5, LRP6 dan FGF8 pada Pesakit Melayu Sumbing Bibir Bukan Sindrom dengan atau Tanpa Sumbing Lelangit)

\section{Nurul Syazana Mohamad ShaH*, Wan Azman Wan Sulaiman, Sarina Sulong \& Ahmad Sukari Halim}

\section{ABSTRACT}

Non-syndromic cleft lip and/or palate (NSCL/P) is a one of the most common birth defects occurs as a result of multi-factorial determinants such as genetic and environmental factors. Genetic factor has been studying widely across different population in identifying genes causing cleft defects. This study aims to validate the role of fibroblast growth factors (FGFs) and signalling molecules Wingless-type (Wnt) to the occurrence of cleft lip and/or palate among Malay population. Tissue skin was obtained from consented NSCL/P patients who underwent the cleft lip repair operation at the upper lip skin area and non NSCL/P individual was obtained from patient having traumatic injury at the lip area as a control. Expression pattern of FGF8, FGF10, Wnt8a, and LRP5/6 were tested and validated using Western Blot $(W B)$ and quantitative Reverse Transcriptase-PCR (qRT-PCR). The fold change difference of FGF8 (0.614 \pm 0.1012 -fold), FGF10 (0.7188 \pm 0.1017-fold) and Wnt8a protein (0.9051 \pm 0.0142 -fold) was downregulated by 1-fold in cleft lip (CL) tissues compared to the normal meanwhile LRP5/6 protein (1.2201 $\pm 0.1404-$ fold) was found upregulated by 1-fold. Validation testing confirmed that expression of FGF8 $(p=0.014)$, Wnt8a (0.0762 \pm 0.0227$)$, LRP5 (0.3577 \pm $0.1362)$ and LRP6 (0.3093 \pm 0.2541$)$ were significantly reduced in CL tissues compared to normal. This is the first study identified defective regulation of Wnt8a, LRP5, LRP6 and FGF8 in NSCL/P among Malays. These novel findings clearly explained the important role of growth factors FGF and Wnt signalling pathway in lip and palate formation during craniofacial development.

Keywords: Craniofacial; gene expression; non-syndromic cleft; protein

ABSTRAK

Sumbing bibir bukan sindrom dengan atau tanpa sumbing lelangit adalah salah satu kecacatan kelahiran yang berlaku disebabkan oleh pelbagai faktor seperti faktor genetik dan persekitaran. Kajian ke atas faktor genetik giat dijalankan terhadap pelbagai populasi berbeza dalam mengenal pasti gen-gen penyebab kecacatan sumbing. Kajian ini bertujuan untuk memvalidasi peranan faktor pertumbuhan 'Fibroblast growth factor' (FGF) dan signal molekul 'Wingless-type'(Wnt) terhadap pembentukan sumbing bibir dengan atau tanpa lelangit dalam kalangan populasi Melayu. Tisu kulit diperoleh dengan kebenaran daripada pesakit sumbing yang mendapat rawatan pembedahan sumbing bibir dan individu bukan sumbing daripada pesakit yang mengalami kecederaan pada bahagian bibir sebagai kawalan. Pengekspresan FGF8, FGF10, Wnt8a dan LRP5/6 diuji dan divalidasi menggunakan teknik 'Western Blot' (WB) dan kuantitatif transkripsi berbalik-PCR' (qRT-PCR). Protein-protein FGF8 (0.614 \pm 0.1012 -fold), FGF10 (0.7188 \pm 0.1017 -fold) dan Wnt8a (0.9051 \pm 0.0142 -fold) pada tisu sumbing menunjukkan penurunan sebanyak sekali ganda berbanding normal manakala protein LRP5/6 (1.2201 \pm 0.1404- fold) menunjukkan peningkatan sekali ganda. Ujian validasi mengesahkan penurunan ekspresi FGF8 ( $p=0.014)$, Wnt8a (0.0762 \pm 0.0227$)$, LRP5 (0.3577 \pm 0.1362$)$ dan LRP6 (0.3093 \pm 0.2541$)$ secara signifikan pada tisu sumbing berbanding normal. Kajian ini adalah yang pertama mengenal pasti kecacatan regulasi Wnt8a, LRP5, LRP6 dan FGF8 pada NSCL/P dalam kalangan Melayu. Penemuan novel ini menjelaskan secara terperinci kepentingan peranan faktor pertumbuhan FGF dan laluan signal Wnt dalam pembentukan bibir dan lelangit ketika pembentukan kraniofasial.

Kata kunci: Ekspresi gen; kraniofasial; protein; sumbing bukan sindrom 


\section{INTRODUCTION}

Non-syndromic cleft lip and/or palate (NSCL/P) is the most common human congenital malformations which occurs approximately 1-2 per 1000 births. A complex process of craniofacial development involving the interaction of cell growth, growth factors and receptors, and apoptosis to guide the convergence and fusion of the facial and palatal processes (Chiquet 2011). It was remarkable that Asian population has highest cleft prevalence at birth compared to the other populations (Mangold et al. 2009). In Malaysia, the highest incidence of clefts was reported among the Chinese compared to the Malays and other races (Boo \&Arshad 1990). However, since this study was conducted in Kelantan district whereas the majority of the residence were Malays, the samples obtained were mostly from the Malays.

Non-syndromic cases for both cleft lip with or without cleft palate are heterogenous with multi-factorial etiology, in which both genetic and environmental factors take place (Shaw et al. 1991). Due to the scarce report on molecular genetic study on NSCL/P formation in Malaysia, we were interested to investigate the role of FGF and Wnt signalling in lip development. The aim of this study was to determine the role of growth factors (FGF8 and FGF10) and signalling molecules (Wnt8a and LRP5/6) to the formation of CL/P among Malays.

The $F G F$ family plays a crucial role in palatogenesis and cause diverse pathologies ranging from morphogenetic disorders to cancer when mutated or inappropriately expressed (Dailey et al. 2005; Nie et al. 2006; Sasaki et al. 2011). Distinct FGFs have been identified in a variety of organisms from nematode and drosophila to mouse and human. It is reported that $F G F$ missense and nonsense mutations contributed to $3-5 \%$ of non-syndromic cleft lip and cleft palate development (Riley et al. 2007; Weng et al. 2018). Disturbance to the development process either by genetic or environmental factors may lead to craniofacial disorders, for example orofacial clefts (Nie et al. 2006). They also have reported that $F G F 8$ play an important role for the initiation and advancing development of submandibular salivary gland and found that the deletion of FGF10 caused cleft palate (Alappat et al. 2005; Nie et al. 2006; Rice et al. 2004). In addition, DNA mutations found in genes encoding FGF proteins and their receptors have shown the importance of FGF signalling in CL/P pathogenesis (Pauws \& Stanier 2007).

Mammalian FGFs control a wide spectrum of biological functions during development and adult life (Ornitz \& Itoh 2001). Well-established role of
FGFs in the regulation of cell proliferation, migration, differentiation and apoptosis during embryonic development has been reported. However, FGF expression and function in adults remain unclear (Fon Tacer et al. 2010). Dysregulation of FGF signalling was discovered in patients with craniosynostosis, skeletal dysplasia syndromes, Kallmann syndrome, and NSCL/P formation (Riley et al. 2007).

A distinct mechanism of Wnt signalling during craniofacial development is known as it involves 10 frizzled receptors and two low density lipoprotein receptor-related protein (Lrp 5 and Lrp6) co-receptors, act through $\beta$-catenin-dependent canonical pathway and the $\beta$ - catenin-independent $\mathrm{Wnt} /$ calcium and planar cell polarity pathways (Logan \& Nusse 2004; Veeman et al. 2003).

Previously, it was reported that Wnt genes and growth factors (nerve growth factor, FGF, and BMPs) involve in tooth bud formation, which are expressed in the oral ectoderm and underlying neural crest tissue (Sperber 2002). Wnt malfunction has been implicated in several diseases such as cancer disease or degenerative disease (Nusse 2005). For example, loss of Wnt3 function in human have caused rare human genetic disorders called Tetramelia that characterized by an absence of limbs (Niemann et al. 2004). The presence of LRP is essential in Wnt pathway as LRP5 or 6 was identified in vertebrates (Nusse 2005). It was reported that an increased bone density at the jaw and palate has been associated with LRP mutation (Boyden et al. 2002; Little et al. 2002). It occurs as a result of single amino acid substitution that makes LRP5 insensitive to inhibit Dickkopf (Dkk)mediated Wnt pathway process, resulting in over-active Wnt signalling in the bone (Boyden et al. 2002). This finding indicated that Wnt signalling mediated by LRP5 is required for maintenance of normal bone density.

Specific genes remain unexplained since NSCL/P development involves both genetic and environmental factors which finally results in heterogeneity in pathogenesis of cleft deformity. Continual research in searching for the global significant contributing genes to the NSCL/P development is indispensable for a preventive measure.

\section{MATERIALS AND METHODS}

\section{SAMPLE COLLECTION}

Tissue samples were obtained from the consented patients who underwent cleft lip repair operation at the upper lip skin area in Hospital Universiti Sains Malaysia 
(Hospital USM) within a period of 1.5 years. All patients aged between 3 months-17 years old. As for control, normal skin was obtained from patients who underwent surgery for trauma at the upper lip area. This study was approved by the Research Ethics Committee (Human) of the Universiti Sains Malaysia, Health Campus, Malaysia per reference USMKK/PPP/JEPeM [258.3.(3)]. Sample size was calculated using Power and Sample Size Program with two independent population proportions formula.

\section{SAMPLE INCLUSION AND EXCLUSION CRITERIA}

\section{Cleft lip patients}

Patients were firstly screened by specialists of plastic surgery. Non-syndromic cleft lip and/or palate patients with one minor anomaly identified such as low-set ears, hypertelorism, clinodactyly, and single palmar crease was included as these anomalies would not interfere with cleft abnormalities. Syndromic cleft lip and/or palate patients, facial clefts and non-syndromic cleft lip and/ or palate patients with any major abnormalities such as heart problem, brain defect detected during the screening were excluded (Shah et al. 2016).

\section{Normal patients}

Patient who was normal with lip pathology excision was included. Patients with non-syndromic or syndromic cleft lip and/or palate or other syndromic diseases were excluded. Patients with brain defect, heart problem or any other major abnormalities were also excluded.

\section{RNA AND PROTEIN EXTRACTION FROM TISSUE BIOPSY}

Tissue samples were minced into smaller pieces before being lysed with lysis buffer (Buffer RLT, Qiagen). Lysed tissues were then homogenized using homogenizer (Glas-Col) to fully disrupt the samples. The lysate was transferred into $2 \mathrm{~mL}$ collection tube for protein extraction. RNA and protein extraction were done using AllPrep DNA/RNA/Protein Mini Kit (Qiagen).

\section{SDS-PAGE AND WESTERN BLOT ANALYSIS}

The protocols were based on previous works with minor modifications (Lim et al. 2011; Meng et al. 2012). The proteins of the sample were separated using sodium dodecylsulfate polyacrylamide gel electrophoresis (SDSPAGE). The electrophoresis was run at $175 \mathrm{~V}$ for $45 \mathrm{~min}$. Then the proteins were carried out for Western Blot.

For protein detection, membrane was probed with antibodies against FGF 8 (ab54756, Abcam), FGF10 (ab54762, Abcam), Wnt8a (ab68028, Abcam), LRP5/6 (ab52215, Abcam), housekeeper beta-actin (mAbcam
8224, Abcam) and secondary antibody goat antimouse (ab97023, Abcam). Chemiluminescence was detected using Image Analyzer and band intensities were quantified using the Image Analyzer and Image $\mathrm{J}$ software. Beta-actin was used as a loading control and all bands were normalized to it. The band for each target was compared to the normal control and the intensity density value (IDV) was normalized to the IDV of beta-actin.

\section{QUANTITATIVE REVERSE-TRANSCRIPTASE PCR (qRT-PCR)}

The cDNA was then generated from $1 \mathrm{mg}$ of RNA using the SuperScript III First Strand Synthesis SuperMix (Invitrogen Laboratories). After reverse transcription, qPCR is then performed to quantify the expression level of FGF8, FGF10, Wnt8a, LRP5, LRP6 and GAPDH as an endogenous control. Human DNA sequence for selected gene were identified using NCBI database and compared with human genome using BLAST program (http://blast.ncbi.nlm.nih.gov) to avoid cross-matching throughout the human genome. Five selected sequences from NCBI were Homo sapiensFGF8 [NM_001206389.1], FGF10 [NM_004465.1], Wnt8a [NM_058244.2], LRP5 [NM_002335.2] and LRP6 [NM_002336.2] and GAPDH was used as a control.

The relative expression ratio in fold change of the target gene can be calculated based on real-time PCR efficiency (E) corrected and expressed in comparison to a reference gene (GAPDH). The average values from triplicates for the targets and endogenous control were calculated.

\section{STATISTICAL ANALYSIS}

Statistical analysis of data was performed using MannWhitney test with SPSS Statistics (SPSS 22, SPSS, Inc., USA). Statistical significance was determined for $\mathrm{p}$ value $<0.05$ and all data was expressed as mean \pm SEM for Western blot and mean \pm standard deviation (sd) for qRT-PCR.

\section{RESULTS AND DISCUSSION}

\section{PROTEIN AND GENE EXPRESSION OF CL/P}

The fold change differences were visualized by western blot. Low band densities of FGFs in CL tissue were obtained but high band densities for normal in comparison to the beta-actin (Figure 1(A)). Estimated size for FGF8 and FGF10 protein was $27 \mathrm{kDa}$ and $37 \mathrm{kDa}$, respectively. Fold change of protein expression (mean \pm SEM) for both FGFs; FGF8 (0.614 \pm 0.1012 -fold $), p=$ 
0.03 and FGF10 $(0.7188 \pm 0.1017$-fold $), p=0.01$ were downregulated by 1 -fold in CL tissue in comparison to normal (Figure 1(B)). FGFs downregulation had been evaluated on graph by calculating the band densities based on Integrity Density Value (IDV) and number of folds using normal as a control. Figure 1(B) shows the dotted line depicts the expression level of normal that has been fixed to 1 to calculate the band densities of the tested $\mathrm{CL} / \mathrm{P}$. Despite small differences in the fold changes of FGF8 and FGF10 in CL/P, FGF8 showed exclusively downregulated compared to FGF10.

Low band densities of LRP5/6 and elevated band densities of Wnt8a were found in normal and CL tissue in comparison to the beta-actin (Figure 2(A)). The estimated size for Wnt8a and LRP5/6 protein was $45 \mathrm{kDa}$ and 170 $\mathrm{kDa}$, respectively. It was detected that the foldchange difference of LRP 5/6 (1.2201 \pm 0.1404 -fold), $\mathrm{p}=0.02$ was upregulated by 1 -fold and Wnt8a $(0.9051 \pm 0.0142$ fold), $\mathrm{p}=0.05$ was downregulated by 1 -fold in $\mathrm{CL}$ in comparison to normal protein. Figure 2(B) shows the dotted line at 1 represents the expression level of normal, which was used as a marker to calculate the band densities of the tested CL.

DNA amplification of $F G F$ showed changing trends of gene expression in CL tissue compared to the normal control (Table 1). FGF8 in CL showed significantly downregulated $(0.1220 \pm 0.0388), \mathrm{p}=0.014$ compared to normal. FGF10 showed contradicted result whereas significant upregulated in CL tissue $(4.0723 \pm 2.3615)$, $\mathrm{p}=0.019$ compared to normal was found. Significant decreased of gene expression for $L R P 5(0.3577 \pm 0.1362)$, LRP6 $(0.3093 \pm 0.2541)$ and Wnt8a $(0.0762 \pm 0.0227)$, $\mathrm{p}=0.019$ found in CL tissue compared to the normal (Table 2). Low gene expression for LRP5 and LRP6 detected in CL tissue but reported as upregulated in protein level. On contrary, Wnt8a gene in CL tissue was reported to be downregulated in both transcriptional and translational stage.
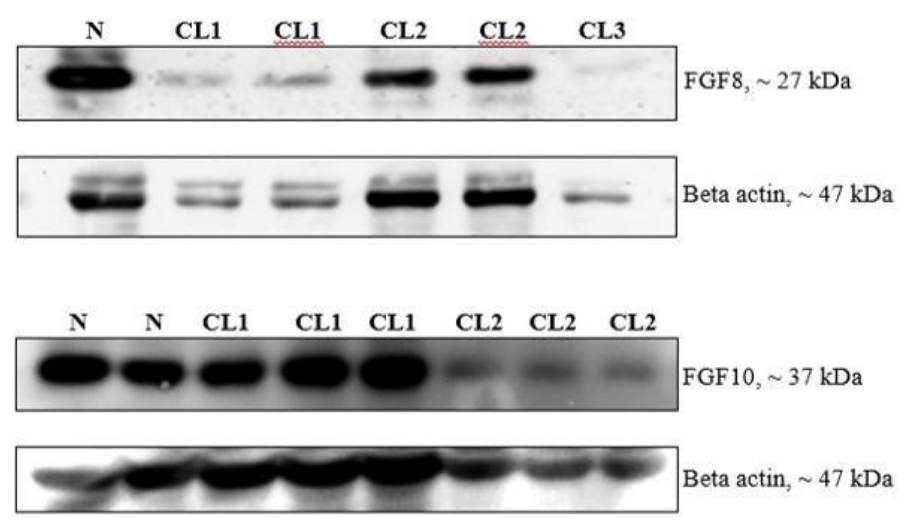

A

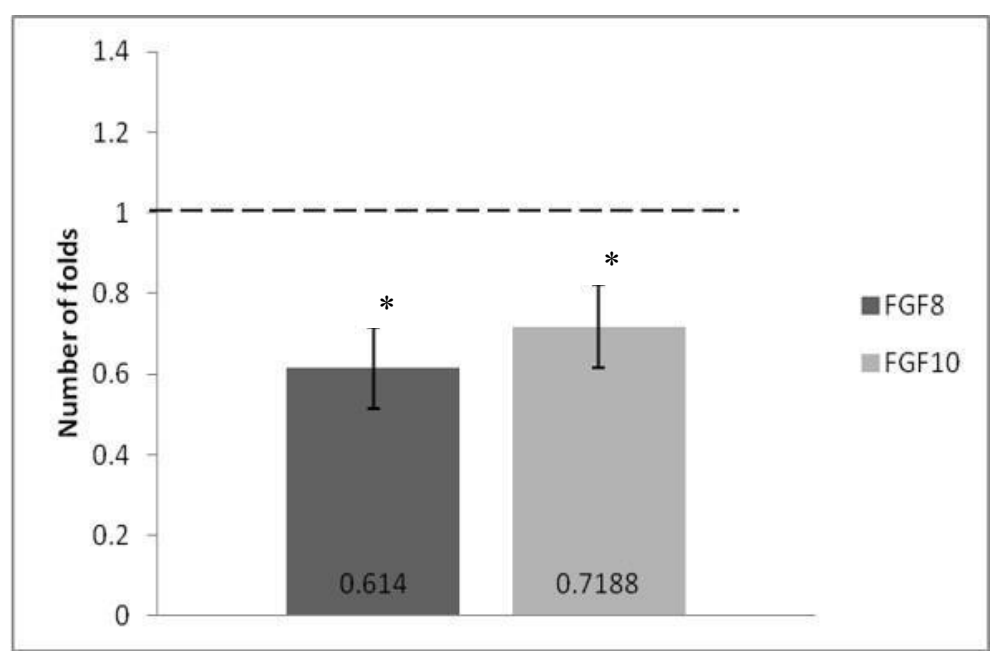

B

FIGURE 1. Expression of FGF8 and FGF10 in normal and CL. A) Protein was extracted from normal and CL tissue and the expression of FGFs were determined by western blotting. The band intensities and size of the proteins were visualised and compared with beta-actin, B) The level of expression in CL for each gene of interests were shown as the fold change in comparison to normal (1-fold). The blots were the representative for the mean fold from the triplicates. ${ }^{*} p<0.05$ compared with control group 

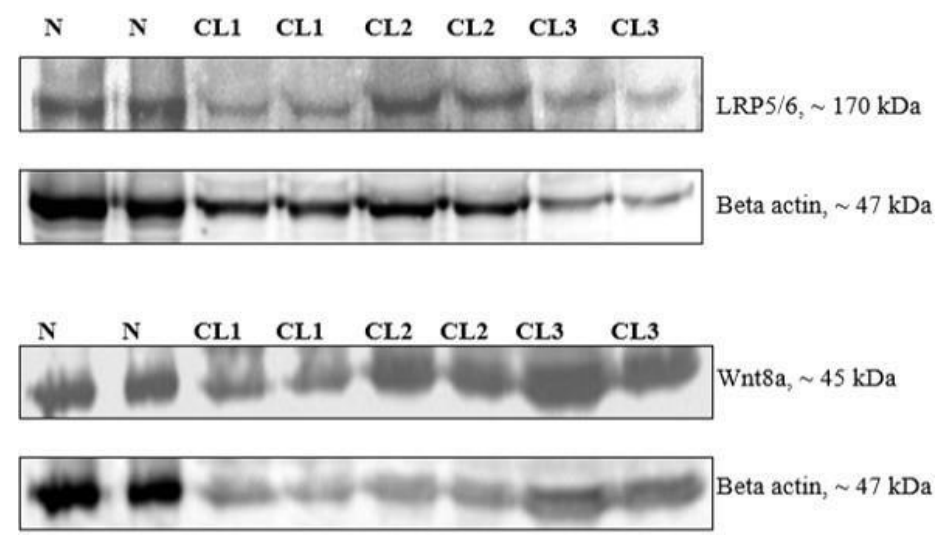

A

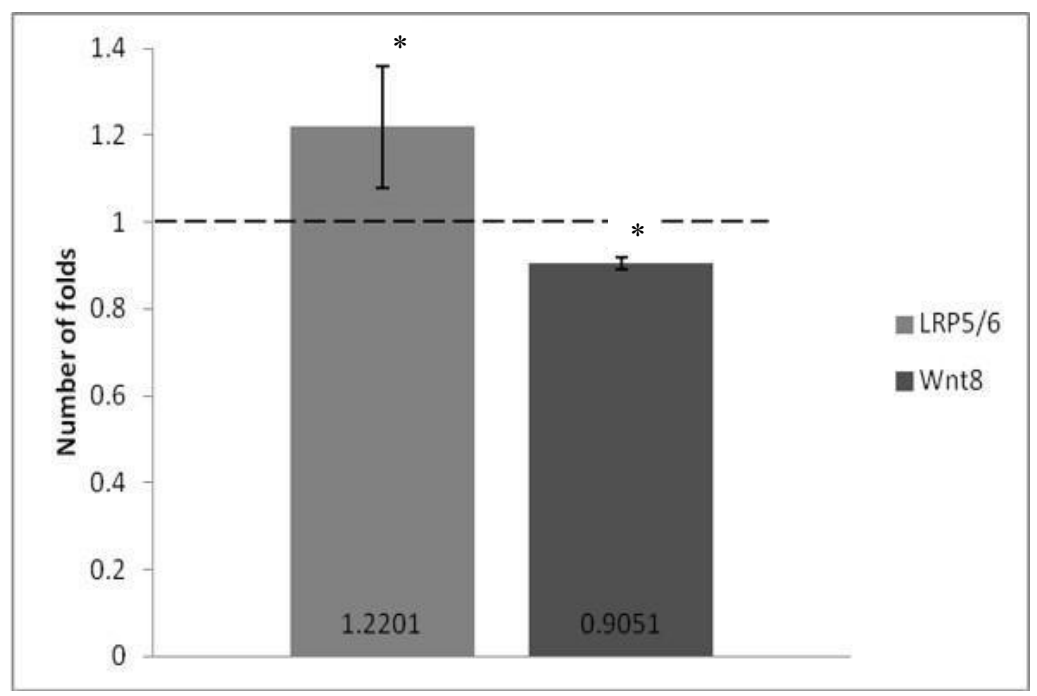

$\mathrm{B}$

FIGURE 2. Expression of LRP5/6 and Wnt8a in normal and CL. A) Protein was extracted from normal and CL tissue and the protein expressions were determined by Western blotting. The band intensities and size of the proteins were visualised and compared with beta-actin, B) The level of protein expression in CL was shown as the fold change in comparison to normal (1- fold). The blots are the representative for the mean \pm SEM for LRP5/6 and Wnt8a from the triplicates. ${ }^{*} \mathrm{p}<$ 0.05 compared with control group

TABLE 1. Expression of FGFs in qRT-PCR analysis. Nonparametric analysis showed significant upregulation and downregulation of FGF8 and FGF10 gene in comparison to normal

\begin{tabular}{lll}
\hline Genes & Mean $\pm \mathrm{sd}$ & $\mathrm{p}$ value \\
\hline \multirow{2}{*}{ FGF8 FGF10 } & $0.1220 \pm 0.0388$ & 0.014 \\
& $4.0723 \pm 2.3615$ & 0.019 \\
\hline
\end{tabular}

Data was presented as mean $\pm \mathrm{sd}$; sd: standard deviation. *Significant ( $\mathrm{p}$ value $<0.05$ ) 
TABLE 2. Wnt $8 a, L R P 5$ and LRP6 expression by qRT-PCR analysis. Nonparametric analysis using MannWhitney test showed significant downregulation of the tested genes in comparison to normal

\begin{tabular}{|c|c|c|}
\hline Genes & Mean \pm sd & $\mathrm{p}$ value \\
\hline LRP5 & $0.3577 \pm 0.1362$ & \\
\hline LRP6 & $0.3093 \pm 0.2541$ & 0.019 \\
\hline Wnt $8 a$ & $0.0762 \pm 0.0227$ & \\
\hline
\end{tabular}

Data was presented as mean $\pm \mathrm{sd}$; sd: standard deviation. ${ }^{*}$ Significant $(\mathrm{p}$ value $<0.05)$

Significant decreased of gene expression for $L R P 5$ $(0.3577 \pm 0.1362), \operatorname{LRP} 6(0.3093 \pm 0.2541)$, and Wnt8a $(0.0762 \pm 0.0227)$ with $\mathrm{p}$ value of 0.019 showed in $\mathrm{CL}$ tissue compared to the normal control. Low gene expression for LRP5 and LRP6 has been detected in CL tissue than reported as upregulated protein level through semi-quantitative protein analysis. On a contrary, Wnt8a gene in CL tissue was reported to be downregulated in both quantitative qPCR and semiquantitative WB analysis.

An association of FGF and NSCL/P has been widely shown as FGF is known to have a crucial role in developmental process. The presence of FGF signalling in epithelia and mesenchyme and also mediated the epithelial-mesenchymal interaction in almost all structures proved its important roles to the early formation (Nie et al. 2006; Snyder-Warwick et al. 2010). FGF8 and FGF10 protein downregulation in CL compared to the normal might indicate the translational process of FGFs was disturbed during developmental process. Similarly, significant low expression of $F G F 8$ in the CL tissue compared to the normal has proven that the $F G F 8$ transcriptional process was also disturbed. It could be concluded that both transcriptional and translational process of $F G F 8$ was disrupted in CL tissue therefore proven its indispensable role during craniofacial development. This could be supported with evidence from previous works that showed FGF signalling play an essential role in craniofacial development in which FGF 8 commonly associated with facial clefts while mutation of FGF10 can cause cleft palate (Nie et al. 2006; Riley et al. 2007).

Even though the study of gene expression derived from tissue lip was not widely investigated, we have successfully showed the importance of FGF in orofacial cleft formation. One study has reported gene expression patterns could be different between what was identified in the lip skin after the embryonic development and what occurs during the development (Davidson 2012). Significant downregulation of FGF8 expression caused loss of function of FGF8 towards the developmental process. This insufficiency facial development has supported its crucial role in early craniofacial patterning and growth (Nie et al. 2006). It was proven that FGF10 expression in palatal process is essential for palate development as the downregulation led to cleft palate formation in WB analysis. However, significant upregulation of FGF10 protein expression in CL compared to normal showed it would be a possible new mechanism occurred that leads to insufficient palatal development.

Silencing of FGF10 function without disturbing the normal expression should be concerned. This was supported by previous studies which the data demonstrated FGF 8 was associated with human disorders of NSCL/P while FGF10 was confirmed involved in cleft palate in mouse models but in human is still unknown or in the borderline significant value (Pauws \& Stanier 2007; Riley et al. 2007). Another one study has also demonstrated that different mechanisms involve in the development of lip and palate in mouse (Liu \& Foley 2011). An identification of muted genes from FGF/FGFR family might discover something new in the future research (Nie et al. 2006).

Others have reported that deletion of FGF10 results in cleft palate while FGF8 is a key signal for the initiation and advancing development of submandibular salivary gland (Alappat et al. 2005; De Moerlooze et al. 2000; Nie et al. 2006; Rice et al. 2004). A widespread expression of paracrine FGF genes in adult tissues has suggested their multiple roles in tissue homeostasis and repair (Fon Tacer et al. 2010). It was reported that paracrine FGF8 knockout mice cause defects in gastrulation, limb development and CNS development, intensely expressed at nasal pits while FGF10 knockout 
mice was critical for epithelial- mesenchymal interactions necessary for the development of epithelial components of multiple organs (Bachler \& Neubüser 2001; Ohuchi et al. 2000; Sakaue et al. 2002; Sasaki et al. 2011; Sun et al. 1999).

Wnt signalling and growth factors play a role in growth and development for example during embryonic induction, epithelial and mesenchymal cellular polarity, cell fate determination, cytoskeletal organization, and cell proliferation (Bejsovec 2005; Chiquet 2011; Dale et al. 2009). It was documented that the expression of Wnt genes during craniofacial development of mammals is crucial especially during the lip and palate formation (Yamaguchi et al. 1999). To the best of our knowledge, this was the first study been carried out and reported in Malaysia on the CL/P tissue of affected individual among the Malay population, in aiming to determine the Wnt signalling mechanism. Novel downregulation of Wnt8a in NSCL/P found in Malay population, depicted its important role and one of the causing genes to craniofacial malformations. Several mouse studies on craniofacial development have also demonstrated that inactivation of genes caused the orofacial clefting in mouse (Chiquet 2011; De Calisto et al. 2005).

In normal pathway, Wnt8a molecules interact with Frizzled (Fz)/LDL receptor related protein (LRP) receptor complex on the cell surface. This complex is then transduced the signal to Dishevelled (Dsh) and Axin and inhibited the degradation of $\beta$-catenin, thus allowed the accumulation of protein in the cytoplasm and nucleus (Logan \& Nusse 2004). However, in our study, reduced of Wnt8a accumulation leads to the poor function of the protein in the nucleus due to the reduced the Fz/LRP complex formation and degradation of $\beta$-catenin. It was documented that loss of a single Wnt gene in vertebrate development can caused obvious different phenotypes either in embryonic lethality, CNS abnormalities to kidney or limb defects (Logan \& Nusse 2004). The phenotype diversity has proved that the Wnt pathway has a distinct transcriptional output. The up or downregulation of Wnt target genes is controlled by the cell, which determines the nature of the response (Logan \& Nusse 2004).

LRP function during the Wnt signalling pathway is indispensable as LRP5 and 6 was identified in vertebrates (Nusse 2005). Nevertheless, it has been proposed that Wnt molecules bind to LRP and Frizzled to form a receptor trimeric complex for signal transduction (Tamai et al. 2000). Thus, any loss of one of them may interfere to the normal initiation of signal transduction. An opposed finding on expression level of LRP 5 and 6 from semiquantitative of WB to quantitative qRT-PCR has shown the different mechanism took place at transcriptional and translational level. Reduced LRP5 and LRP6 gene expression in CL, which was also similarly found in Wnt8a gene devoted mutation of these genes occurred in transcriptional process. Therefore, the normal initiation of Wnt signal transduction was disturbed. However, upregulation of LRP5/6 protein expression later in translational process could not be explained.

LRP is processed in the endoplasmic reticulum (ER) trans-golgi and invoke signal transduction pathway at the cell surface. The translation process of LRP protein and its transportation from ER to the cell surface requires specific molecules (Culi \& Mann 2003; Hsieh et al. 2003). However, the importance of LRP was inhibited by potent Wnt-signalling inhibitors called Dkk protein. Dkk protein forms a complex with LRP and acts by inactivating LRP to bind with Wnt. In addition, LRP mutation has been identified that caused increased bone density in jaw and palate (Boyden et al. 2002; Little et al. 2002). Previous study on mice has shown that deletion of LRP6 in mice has resulted in CL/P, in which LRP6 deletion caused inactivation of $\mathrm{Wnt} / \beta$-catenin signalling in orofacial primordia (Song et al. 2009).

Non-syndromic orofacial clefts are heterogenous, whereas both environmental and genetic factors play their role in cleft formation. Significant novel downregulation of Wnt8a, LRP5, and LRP6 among Malays during the craniofacial development proved their role during craniofacial development and their loss of function was a causing factor of NSCL/P formation.

\section{CONCLUSION}

Novel finding on loss of function in Wnt8a, LRP5, and $L R P 6$ as well as known $F G F 8$ in Malay population confirmed the important role of these genes in craniofacial development. Although the contributing genes in NSCL/P varied among population, the role of FGF8, Wnt8a, and LRP5 and LRP6 in NSCL/P among the Malays was confirmed. However, role of FGF10 was still unclear. Hence, complex FGF signalling pathway analysis in vitro in larger sample size should further be carried in future to clarify the molecular mechanism that contributes to NSCL/P formation in Malay population. Obtaining normal tissue samples were the main limitation of this study since the lip excision from traumatic injury and pathological excision was rare among younger patients. 
Plus, the size of the samples was very small, thus limited for various tests and duplication.

\section{ACKNOWLEDGEMENTS}

The authors were grateful to all the patients and parents for their cooperation. The study was supported by the USM Research University (RU) grant 1001/PPSP/812083 and USM Short Term Grant 304/PPSP/6315126. The authors declared there is no competing interest.

\section{REFERENCES}

Alappat, S.R., Zhang, Z., Suzuki, K., Zhang, X., Liu, H., Jiang, R., Yamada, G. \& Chen, Y. 2005. The cellular and molecular etiology of the cleft secondary palate in $\mathrm{Fg} f 10$ mutant mice. Developmental Biology 277(1): 102-113.

Bachler, M. \& Neubüser, A. 2001. Expression of members of the $F g f$ family and their receptors during midfacial development. Mechanisms of Development 100(2): 313316.

Bejsovec, A. 2005. Wnt pathway activation: New relations and locations. Cell 120(1): 11-14.

Boo, N. \& Arshad, A. 1990. A study of cleft lip and palate in neonates born in a large Malaysian maternity hospital over a 2-year period. Singapore Medical Journal 31(1): 59-62.

Boyden, L.M., Mao, J., Belsky, J., Mitzner, L., Farhi, A., Mitnick, M.A., Wu, D., Insogna, K. \& Lifton, R.P. 2002. High bone density due to a mutation in LDL-receptor-related protein 5. New England Journal of Medicine 346(20): 1513-1521.

Chiquet, B.T. 2011. Gene discovery in nonsyndromic cleft lip with or without cleft palate. UT GSBS Dissertations and Theses (Open Access). Paper 131.

Culi, J. \& Mann, R.S. 2003. Boca, an endoplasmic reticulum protein required for wingless signaling and trafficking of LDL receptor family members in Drosophila. Cell 112(3): 343-354.

Dailey, L., Ambrosetti, D., Mansukhani, A. \& Basilico, C. 2005. Mechanisms underlying differential responses to Fgf signaling. Cytokine \& Growth Factor Reviews 16(2): 233- 247.

Dale, R.M., Sisson, B.E. \& Topczewski, J. 2009. The emerging role of Wnt/Pcp signaling in organ formation. Zebrafish 6(1): 9-14.

Davidson, B.N. 2012. Examining cleft lip and palate as a lifelong disease: Genetic investigation of causes and outcomes. Dissertation. University of Iowa Health Care (Unpublished).

De Calisto, J., Araya, C., Marchant, L., Riaz, C.F. \& Mayor, R. 2005. Essential role of non- canonical Wnt signalling in neural crest migration. Development 132(11): 2587-2597.

De Moerlooze, L., Spencer-Dene, B., Revest, J., Hajihosseini, M., Rosewell, I. \& Dickson, C. 2000. An important role for the IIIb isoform of fibroblast growth factor receptor 2 (FGFR2) in mesenchymal-epithelial signalling during mouse organogenesis. Development 127(3): 483-492.
Fon Tacer, K., Bookout, A.L., Ding, X., Kurosu, H., John, G.B., Wang, L., Goetz, R., Mohammadi, M., Kuro-o, M., Mangelsdorf, D.J. \& Kliewer, S.A. 2010. Research resource: Comprehensive expression atlas of the fibroblast growth factor system in adult mouse. Molecular Endocrinology 24(10): 2050-2064

Hsieh, J.C., Lee, L., Zhang, L., Wefer, S., Brown, K., DeRossi, C., Wines, M.E., Rosenquist, T. \& Holdener, B.C. 2003. Mesd encodes an Lrp5/6 chaperone essential for specification of mouse embryonic polarity. Cell 112(3): 355-367.

Lim, C.K., Halim, A.S., Zainol, I. \& Noorsal, K. 2011. In vitro evaluation of a biomedical- grade bilayer chitosan porous skin regenerating template as a potential dermal scaffold in skin tissue engineering. International Journal of Polymer Science 2011: Article ID. 645820.

Little, R.D., Folz, C., Manning, S.P., Swain, P.M., Zhao, S.C., Eustace, B., Lappe, M.M., Spitzer, L., Zweier, S., Braunschweiger, K. \& Benchekroun, Y. 2002. A mutation in the LDL receptor-related protein 5 gene results in the autosomal dominant high-bone-mass trait. The American Journal of Human Genetics 70(1): 11-19.

Liu, W. \& Foley, A.C. 2011. Signaling pathways in early cardiac development. Wiley Interdisciplinary Reviews: Systems Biology and Medicine 3(2): 191-205.

Logan, C.Y. \& Nusse, R. 2004. The Wnt signaling pathway in development and disease. Annu. Rev. Cell Dev. Biol. 20: 781-810.

Mangold, E., Reutter, H., Birnbaum, S., Walier, M., Mattheisen, M., Henschke, H., Lauster, C., Schmidt, G., Schiefke, F., Reich, R.H. \& Scheer, M. 2009. Genome-wide linkage scan of nonsyndromic orofacial clefting in 91 families of central European origin. American Journal of Medical Genetics Part A 149(12): 2680-2694.

Meng, T., Shi, J.Y., Wu, M., Wang, Y., Li, L., Liu, Y., Zheng, Q., Huang, L. \& Shi, B. 2012. Overexpression of mouse TTF-2 gene causes cleft palate. Journal of Cellular and Molecular Medicine 16(10): 2362-2368

Niemann, S., Zhao, C., Pascu, F., Stahl, U., Aulepp, U., Niswander, L., Weber, J.L. \& Müller, U. 2004. Homozygous Wnt3 mutation causes tetra-amelia in a large consanguineous family. The American Journal of Human Genetics 74(3): 558-563.

Nusse, R. 2005. Wnt signaling in disease and in development. Cell Research 15(1): 28-32.

Nie, X., Luukko, K. \& Kettunen, P. 2006. Fgf signalling in craniofacial development and developmental disorders. Oral Diseases 12(2): 102-111.

Ohuchi, H., Hori, Y., Yamasaki, M., Harada, H., Sekine, K., Kato, S. \& Itoh, N. 2000. Fgf10 acts as a major ligand for Fgf receptor 2 IIIb in mouse multi-organ development. Biochemical and Biophysical Research Communications 277(3): 643-649.

Ornitz, D.M. \& Itoh, N. 2001. Fibroblast growth factors. Genome Biol. 2(3): 1-12.

Pauws, E. \& Stanier, P. 2007. Fgf signalling and sumo modification: New players in the aetiology of cleft lip and/or palate. TRENDS in Genetics 23(12): 631-640. 
Rice, R., Spencer-Dene, B., Connor, E.C., Gritli-Linde, A., McMahon, A.P., Dickson, C. \& Rice, D.P. 2004. Disruption of $\mathrm{Fgf10} / \mathrm{Fg} f \mathrm{r} 2 \mathrm{~b}$-coordinated epithelial-mesenchymal interactions causes cleft palate. Journal of Clinical Investigation 113(12): 1692.

Riley, B.M., Mansilla, M.A., Ma, J., Daack-Hirsch, S., Maher, B.S., Raffensperger, L.M. \& Mohammadi, M. 2007. Impaired $F g f$ signaling contributes to cleft lip and palate. Proceedings of the National Academy of Sciences 104(11): 4512-4517.

Sakaue, H., Konishi, M., Ogawa, W., Asaki, T., Mori, T., Yamasaki, M. \& Kasuga, M. 2002. Requirement of fibroblast growth factor 10 in development of white adipose tissue. Genes \& Development 16(8): 908-912.

Sasaki, S., Miyake, A., Ohta, H., Konishi, M., Itoh, N. \& Nakajima, Y. 2011. The Fgf Family in Humans, Mice, and Zebrafish: Development, Physiology, and Pathophysiology: INTECH Open Access Publisher.

Shah, N.S.M., Salahshourifar, I., Sulong, S., Sulaiman, W.A.W. \& Halim, A.S. 2016. Discovery of candidate genes for nonsyndromic cleft lip palate through genome-wide linkage analysis of large extended families in the Malay population. BMC Genetics 17(1): 1-9.

Shaw, G.M., Croen, L.A. \& Curry, C.J. 1991. Isolated oral cleft malformations: Associations with maternal and infant characteristics in a California population. Teratology 43(3): 225-228.

Snyder-Warwick, A.K., Perlyn, C.A., Pan, J., Yu, K., Zhang, L. \& Ornitz, D.M. 2010. Analysis of a gain-of-function FGFR2 crouzon mutation provides evidence of loss of function activity in the etiology of cleft Palate. Proceedings of the National Academy of Sciences 107(6): 2515-2520.

Song, L., Li, Y., Wang, K., Wang, Y.Z., Molotkov, A., Gao, L., Zhao, T., Yamagami, T., Wang, Y., Gan, Q. \& Pleasure, D.E. 2009. Lrp6-mediated canonical Wnt signaling is required for lip formation and fusion. Development 136(18): 31613171.

Sperber, G.H. 2002. Craniofacial embryogenesis: Normal developmental mechanisms. In Understanding Craniofacial Anomalies, edited by Mooney, M.P. \& Siegel, M.I. Wiley Online Library. pp. 29-59.

Sun, X., Meyers, E.N., Lewandoski, M. \& Martin, G.R. 1999. Targeted disruption of $F g f 8$ causes failure of cell migration in the gastrulating mouse embryo. Genes \& Development 13(14): 1834-1846.
Tamai, K., Semenov, M., Kato, Y., Spokony, R., Liu, C., Katsuyama, Y., Hess, F., Saint-Jeannet, J.P. \& He, X. 2000 LDL-receptor-related proteins in Wnt signal transduction. Nature 407(6803): 530-535.

Veeman, M.T., Axelrod, J.D. \& Moon, R.T. 2003. A second canon: Functions and mechanisms of B-catenin-independent Wnt signaling. Developmental Cell 5(3): 367-377.

Weng, M., Chen, Z., Xiao, Q., Li, R. \& Chen, Z. 2018. A review of Fgf signaling in palate development. Biomedicine \& Pharmacotherapy 103: 240-247.

Yamaguchi, T.P., Bradley, A., McMahon, A.P. \& Jones, S. 1999. A Wnt5a pathway underlies outgrowth of multiple structures in the vertebrate embryo. Development 126(6): 1211-1223.

Nurul Syazana Mohamad Shah* \& Wan Azman Wan Sulaiman Reconstructive Science Unit

School of Medical Sciences

Health Campus, Universiti Sains Malaysia

16150 Kubang Kerian, Kelantan Darul Naim Malaysia

Sarina Sulong

Human Genome Centre

School of Medical Sciences

Health Campus, Universiti Sains Malaysia

16150 Kubang Kerian, Kelantan Darul Naim

Malaysia

Ahmad Sukari Halim

Director Office

Hospital Universiti Sains Malaysia Health Campus

16150 Kubang Kerian, Kelantan Darul Naim Malaysia

*Corresponding author; email: syazanashah@usm.my

Received: 23 September 2020

Accepted: 1 March 2021 